\title{
Electrical and Electronic Equipment Consumption and E-waste Generation in Bangladesh: Temporal and Spatial View
}

\section{Md. Zahidul Islam}

Assistant Professor, Geography and Environment, Directorate of Secondary and Higher Education, Ministry of Education, Dhaka, BANGLADESH

Corresponding Contact:

Email: miazahid@gmail.com

Manuscript Received: 01 June 2019 - Revised: 01 August 2019 - Accepted: 16 August 2019

\begin{abstract}
Socio-economic and demographic conditions play an important role to determine pattern and magnitude of electrical and electronic equipment (EEE) consumption in Bangladesh. The urban area is considered the potential hot spot of e-waste generation as consumption of EEE is higher here than the rural area due to population concentration, economic wellbeing, and cultural orientation. Bangladesh spends a huge amount on importing EEE every year. The paper is to go into electronic equipment consumption pattern in Bangladesh pointing potential sources of e-waste generation. Data from Bangladesh Bureau of Statistics on ICT use and access by household and individual; World Bank consumption database and other sources are revealed, compiled and processed. District wise data are analyzed and presented using Arc GIS software. The study finds that consumption share of EEE is considerably high in lowest and low-income groups. Population structure is found significant in EEE consumption pattern. According to the study, 15-24 years age group which represents the lowermost segment of population but consume the highest share of ICT in terms of computer, internet and cellphone in Bangladesh. Dhaka is the single uppermost EEE consuming city regarding computer, television, mobile phone, and fridge. Divisional headquarters and some other district headquarters are also fallen in potential e-waste generating zone as they are in top ten EEE consuming districts. The pattern of electrical and electronic equipment consumption influences the type and magnitude of e-waste generation in many ways. So, understanding EEE consumption pattern might be useful as an input to e-waste management planning.
\end{abstract}

Keywords: Electrical and Electronic Equipment, Consumption, E-waste, Bangladesh

This article is is licensed under a Creative Commons Attribution-NonCommercial 4.0 International License.

Attribution-NonCommercial (CC BY-NC) license lets others remix, tweak, and build upon work non-commercially, and

although the new works must also acknowledge \& be non-commercial.

\section{INTRODUCTION}

Bangladesh is at the preliminary stage regarding formal electronic waste (e-waste) management. Recently some informal e-waste management activities are becoming visible centering Dhaka, the capital city of Bangladesh. In Bangladesh per capita e-waste generation is fewer than the developed countries, but the total volume of e-waste 
generated here might not be ignored due to large population size. Moreover, consumption of electrical and electronic equipment (EEE) is increasing at a high rate for rapid economic growth; fascination to digital sphere of the young folks; and immense patronization and encouragement of the government in ICT use under 'Digital Bangladesh' and 'Access to Information (a2i)' programs. It is difficult to measure e-waste generated in Bangladesh because neither formal e-waste management initiative is introduced here neither intensive survey on the issue is done. Finding and analyzing the pattern of EEE consumption might be helpful for visualizing potential e-waste sources in Bangladesh as e-waste generation is directly related to its consumption volume and pattern.

Research on e-waste management in Bangladesh got momentum in 2010 after a project ran by Environmental and Social Development Organization (ESDO) in Dhaka and Chittagong on e-waste survey (Shahriar, et al., 2010). In collaboration of Association for Progressive Communication (APC) and Bytes for All a study on ICTs and environmental sustainability reports 32.04 percent tele-density in Bangladesh in 2008 (Partha \& Hasan, 2011). The situation of international trade and traffic of rubbish electronics in Bangladesh is worsen as huge number of rubbish electronics enter here from China, Singapore, South Korea, Taiwan, Malayasia, and Hong Kong (Lepawsky \& Billah, 2011). Karim et al. (2014) and Alam \& Khalid (2015) also focused on e-waste situation, legal framework, environmental sustainability and informal recycling of e-waste in Bangladesh.

E-waste generation depends on electrical and electronic appliances consumption which is directly related to the concentration of the urban population and level of urbanism. It is observed through an indigenous study by Bangladesh Bureau of Statistics that growth of urban population in Bangladesh leaps after liberation in 1971(Government of Bangladesh, 2014). The first census in 1901 shows the percentage of urban population only 2.34 and the rate of growth was at steady state till 1961. The first census after the liberation, in 1974 shows the level of urbanization as 8.78, but in just six years, it jumped to 15.54 in 1981 as a large number of the population moved from rural area to urban area, particularly to Dhaka for the sake of good job as well as a better life. In the last census in 2011, the percentage of urban population reached 28.00 and the total number of urban population exceeds 30 million (Government of Bangladesh, 2014). These people consume electrical and electronic appliances most and are considered as the potential e-waste generator.

Graph 1: Time Series of Volume of Urban Population, 1901 - 2011 (Government of Bangladesh, 2014)

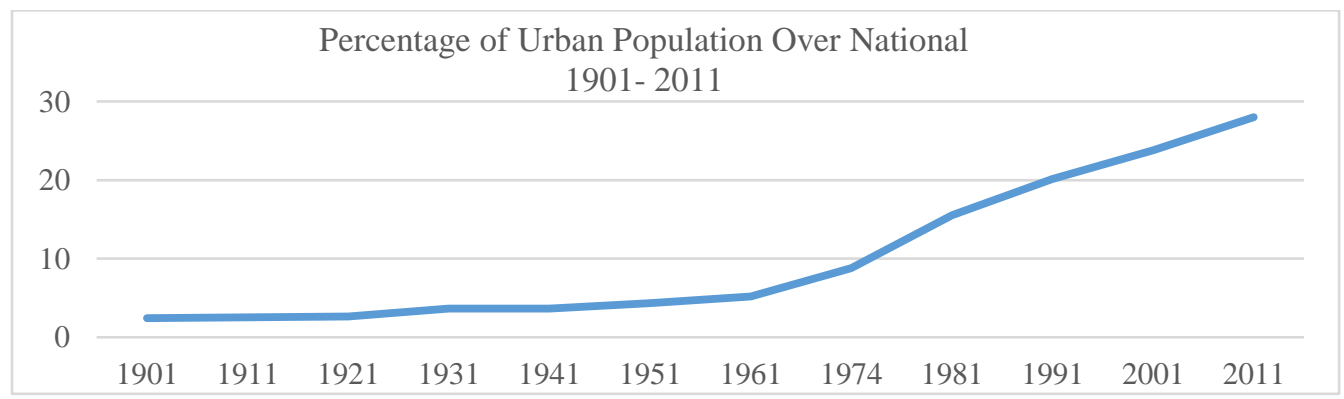

\section{Aim and Objective}

This paper is aimed to know the potential sources of e-waste generation in Bangladesh with temporal and spatial dimensions. For this, the initiative was taken to visualize the consumption pattern of electronic and electrical equipment as it leads to the understanding of the e-waste generation potentiality. 


\section{Methodology}

This paper is based on material searched, reviewed, and compiled from different relevant sources of documents, data sheets, websites, and articles published in journals and websites. Collected secondary data are assembled, analyzed, and presented in forms of tables, graphs and a map. Suitable mapping tools of ArcGIS software are applied to analyze and present data in map format. Lack of uniformity and scarcity of data related to e-waste generation in Bangladesh make the study limited in viewing consumption pattern of electrical and electronic equipment for making understand on e-waste generation indirectly.

\section{Discussion AND RESULT}

Bangladesh is enjoying an expected economic growth with some social and cultural development for recent years. Vast number of population in Bangladesh entered into the earning workforce and their purchasing power is increasing. Considering socioeconomic and demographic phenomena, consumption of different electronic appliances, e.g. household appliances, information processing equipment, telephone services, and ICT equipment increased significantly.

\section{Consumption of Electronics and ICT by Income Group}

A survey on household income and expenditure by the World Bank in 2010 shows that total expenditure in Telephone and ICT sector (mostly smartphone and other telecommunication items) is much higher than Major Household Appliance, e.g. fridge, air conditioner, washing machine, etc and Information Processing Equipment sector e.g. personal computer, laptop (The World Bank, 2010). Data presented in the survey report also implies that consumption in the urban area is higher than in rural area. Though the margin is small but the significance is a big deal because in Bangladesh merely one-third of the total population lives in the urban area. And this one-third consume more than the rest two-third live in rural area. It indicates that the consumption of electrical and electronic equipment is highly concentrated in the urban area, especially in larger cities of Bangladesh and generation of e-waste is seemed to be localized highly in these urban centers.

Table 1: Bangladesh Consumption Share 2010 by Sector, Area and Consumption Segment. (Figures in Million Taka) (The World Bank, 2018)

\begin{tabular}{|l|c|c|c|c|c|c|}
\hline \multicolumn{1}{|c|}{ Sector } & Level & All & Lowest & Low & Middle & Higher \\
\hline \multirow{4}{*}{ Major HH Appliances } & National & 5480.72 & 1954.63 & 2704.01 & 617.06 & 205.02 \\
\cline { 2 - 7 } & Rural & 2891.14 & 1385.69 & 1162.46 & 342.99 & 0.00 \\
\cline { 2 - 7 } & Urban & 2589.58 & 568.94 & 1541.55 & 274.07 & 205.02 \\
\hline \multirow{2}{*}{$\begin{array}{l}\text { Audio-visual, photographic and } \\
\text { Information Processing Equipment }\end{array}$} & National & 10178.92 & 4947.21 & 5047.95 & 145.80 & 37.79 \\
\cline { 2 - 7 } & Rural & 5269.17 & 3109.74 & 2078.57 & 80.87 & 0.00 \\
\cline { 2 - 7 } & Urban & 4909.75 & 1837.47 & 2969.38 & 64.93 & 37.97 \\
\hline \multirow{3}{*}{ Telephone and Telefax Services $^{2}$} & National & 78564.54 & 44826.81 & 31665.39 & 1954.70 & 117.64 \\
\cline { 2 - 7 } & Rural & 36625.60 & 28326.48 & 8045.24 & 253.88 & 0.00 \\
\cline { 2 - 7 } & Urban & 41938.94 & 16500.33 & 23620.14 & 1700.82 & 117.64 \\
\hline \multirow{2}{*}{ ICT $^{3}$} & National & 88815.66 & 49804.91 & 36742.62 & 2108.61 & 159.52 \\
\cline { 2 - 7 } & Rural & 41930.48 & 31461.08 & 10134.65 & 334.75 & 0.00 \\
\cline { 2 - 7 } & Urban & 46885.18 & 18343.83 & 26607.97 & 1773.86 & 159.52 \\
\hline
\end{tabular}

1 http://datatopics.worldbank.org/consumption/product/Audio-Visual,-Photographic-and-InformationProcessing-Equipment

2 http://datatopics.worldbank.org/consumption/product/Telephone-and-Telefax-Services

3 http://datatopics.worldbank.org/consumption/sector/ICT 
Note: The World Bank categorized household in developing countries in four consumption segments for the Global Consumption Database-lowest, low, middle, and higher. They are based on global income distribution data, which rank the global population by income per capita. The lowest consumption segment corresponds to the bottom half of the worldwide distribution or the 50th percentile and below, the low consumption segment to the 51st-75th percentiles; the middle consumption segment to the 76th-90th percentiles; and the higher consumption segment to the 91st percentile and above. Four thresholds were used to establish the consumption segments: Below USD 2.97 income per capita a day were considered the lowest; Low section was with per capita income between USD 2.97 and 8.44 a day; Middlebetween USD 8.44 and 23.03; and Higher-above USD 23.03per capita a day (The World Bank, 2018).

Graph 2: Bangladesh Consumption Share of different electronics and ICT (Figures in Million Taka) (The World Bank, 2018)

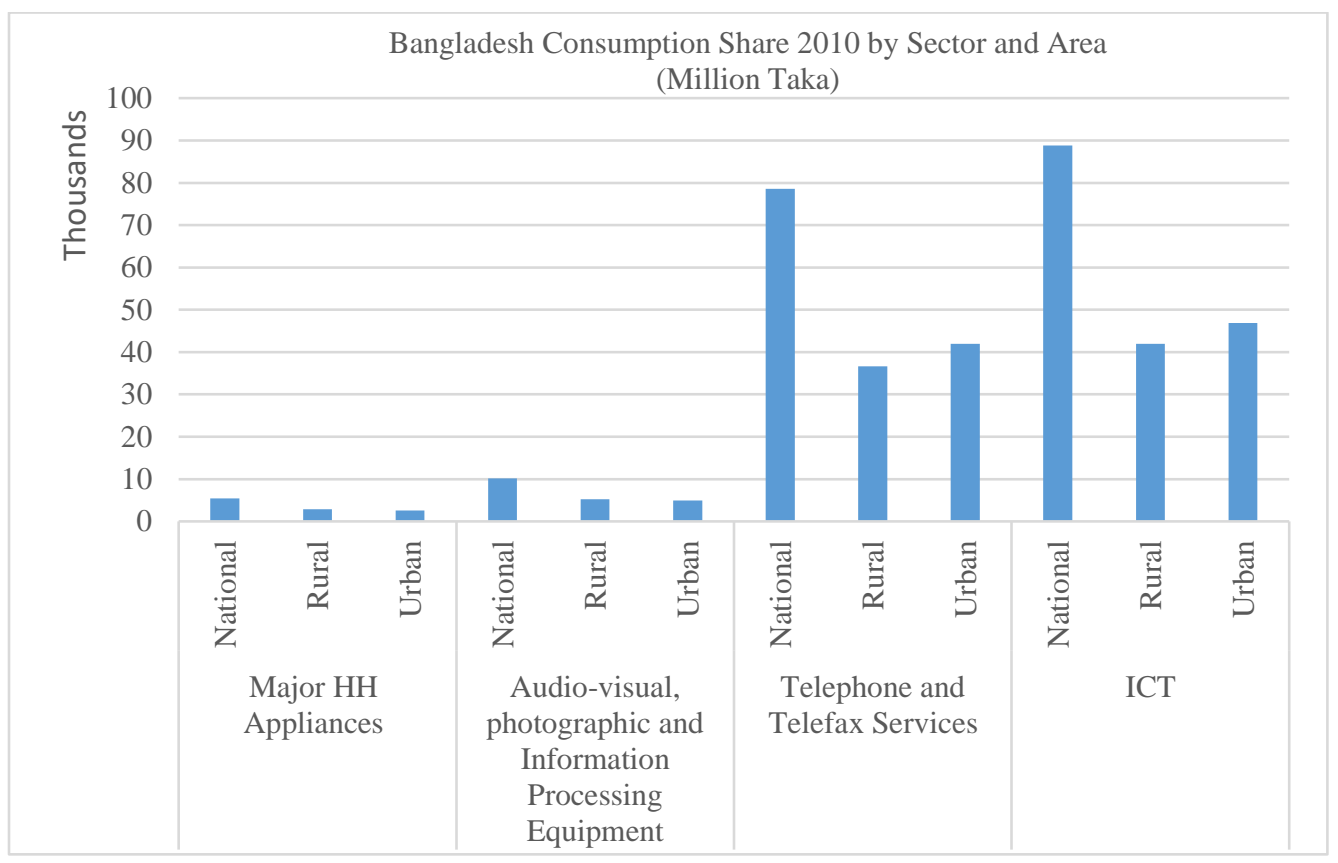

\section{ICT Use and Access by Age, residence, and regional variation}

Access to information (a2i) is a government agenda under 'Digital Bangladesh' promotion. Following the campaign, Bangladesh is now observing ICT excitement in almost every sphere of government activities. The table shows individual level ICT indicator in Bangladesh by age group. It implies that 18.1 percent population in Bangladesh falls into 15-24 year age group and this group is using ICT more. 10.5 percent individuals in this age group possess a personal computer and 12 percent population of this age group have access to the internet, and 90.3 percent population in the age group 15-24 use cell-phone. Though the percentage of computer and internet use is low, it is increasing at a high rate. As 53.5 percent of the population are below 24 in short future user of computer and internet might reach at the rate of cell phone use.

Table 2: Individual level ICT Indicators by age group (Population five year and above) (Government of Bangladesh, 2015)

\begin{tabular}{|l|c|c|c|c|}
\hline \multicolumn{1}{|c|}{ Age group } & Population \% & Computer & Internet & Cell phone \\
\hline Bangladesh & 100 & 5.9 & 7.1 & 80.4 \\
\hline Less than 15 & 35.4 & 2.4 & 1.5 & 58.7 \\
\hline $15-24$ & 18.1 & 10.5 & 12.0 & 90.3 \\
\hline $25-74$ & 46.5 & 5.8 & 7.7 & 86.2 \\
\hline
\end{tabular}


The scenario of ICT consumption is not the same in rural and urban Bangladesh. Report on household level ICT indicator in 2013 indicates this deference. In Bangladesh 5.7 percent of households have provision to a computer; 87.7 percent of households use cell-phone; 46 percent of households can enjoy television of their own, and 4.8 percent of households have access to the internet. But, in rural area the figures almost half from that of national level except cell-phone, and in the urban area it is more or less double from the national average. In the municipal area, use of ICT at the household level is more significant. In City Corporation area 35.9 percent household use a computer; 97.8 possesses cell phone; 96 percent household have television of their own, and 19.6 percent of household have access to internet facility. It indicates that consumption of electronics appliances and ICT products concentrate highly in City Corporation (CC) area of Bangladesh. So, these particular area has the high potentiality as sources of e-waste generation.

Table 3: Household-level ICT Indicators 2013 by area (\%) (Government of Bangladesh, 2015)

\begin{tabular}{|l|c|c|c|c|c|c|}
\hline \multicolumn{1}{|c|}{ Category } & Computer & Cell phone & Land phone & Radio & Television & Internet \\
\hline Bangladesh & 5.7 & 87.7 & 3.1 & 13.9 & 46.0 & 4.8 \\
\hline Rural & 1.7 & 85.2 & 1.1 & 13.1 & 33.0 & 2.1 \\
\hline Urban & 16.0 & 94.1 & 8.1 & 15.7 & 79.0 & 11.6 \\
\hline Urban (excluding CC) & 6.4 & 92.4 & 2.7 & 12.3 & 70.9 & 7.8 \\
\hline Urban ( only CC) & 35.9 & 97.8 & 19.5 & 22.8 & 96.0 & 19.6 \\
\hline
\end{tabular}

Note: CC stands for City Corporation.

City Corporation area is the hub of ICT and electronics consumption and hot spot of ewaste generation as well. There is a deviation in magnitude of household level ICT indicators in different CC estimated in 2013. At present Bangladesh has 12 City Corporation area- those are Dhaka North, Dhaka South, Chittagong, Rajshahi, Khulna, Sylhet, Barisal, Narayanganj, Gazipur, Comilla, Rangpur, and Mymensingh but data is available for seven older City Corporation which is significant enough to present the spatial deviation in ICT use.

A report from Bangladesh Bureau of Statistics (BBS) says the highest 48.3 percent of household in Dhaka City (north and south combined) use computer followed by Chittagong (20.9\%) and Sylhet (20.6\%). Barisal, Khulna, and Rajshahi are at around 14 percent. On the other hand, 12 percent of households in Rangpur City use a computer at home which is the lowest in percentage. Use of cell phone and television is all most at the saturated state in all the City Corporations. Study shows, 97.8 percent of households in Bangladesh use cell-phone, Dhaka is in the top with 99.7 percent and Khulna at lowest position with 93.2 percent. On the other hand, 96 percent households in Bangladesh enjoy television of their own with highest in Sylhet $(98.1 \%)$ and lowest $(87.5 \%)$ in Barisal. There is a similarity in internet use with the pattern of computer use in Bangladesh. Dhaka with 22.8 percent internet using households stands above the national average (19.6\%). Household level internet use in Rangpur City is significantly low. There only 6 percent of households have access to internet connection.

An indication is clear here that, the situation of Dhaka City regarding the provision of ICT and electronics is different from other cities and of course from the rural area. In all indicators, the percentage of household using computer, cell phone, land phone, radio, television, and internet, Dhaka is significantly above the national average with a minor exception. Considering the data, an implication may be drawn that Dhaka is unique in electronics consumption and e-waste generation in Bangladesh as well. 
Table 4: Household-level ICT Indicators 2013 by City Corporation (Government of Bangladesh, 2015)

\begin{tabular}{|l|c|c|c|c|c|c|}
\hline \multirow{2}{*}{$\begin{array}{c}\text { City } \\
\text { Corporations }\end{array}$} & \multicolumn{5}{|c|}{ Percent of households have the provision of } \\
\cline { 2 - 7 } & Computer & Cell phone & Land phone & Radio & Television & Internet \\
\hline Bangladesh & 35.9 & 97.8 & 22.8 & 19.5 & 96.0 & 19.6 \\
\hline Barisal & 14.1 & 94.3 & 15.8 & 12.0 & 87.5 & 11.7 \\
\hline Chittagong & 20.9 & 95.9 & 15.8 & 13.8 & 96.4 & 16.7 \\
\hline Dhaka & 48.3 & 99.7 & 26.4 & 23.5 & 96.7 & 22.8 \\
\hline Khulna & 14.7 & 93.6 & 20.9 & 13.4 & 94.5 & 17.7 \\
\hline Rajshahi & 14.2 & 93.2 & 17.0 & 13.1 & 96.5 & 11.0 \\
\hline Rangpur & 12.0 & 94.5 & 22.4 & 10.5 & 88.8 & 6.0 \\
\hline Sylhet & 20.6 & 96.3 & 23.4 & 18.2 & 98.1 & 15.7 \\
\hline
\end{tabular}

Note: Data from Comilla, Narayangang, and Gazipur CC are not available

Graph 2: Household-level ICT Indicators 2013 by City Corporation (Government of Bangladesh, 2015)

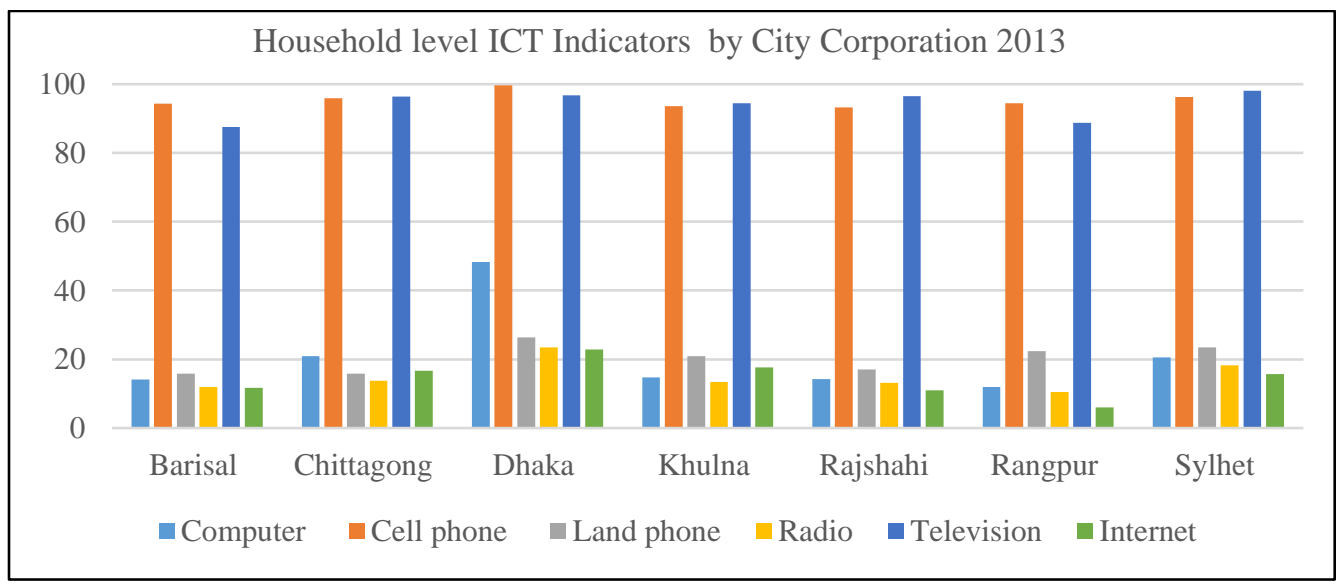

Temporal Changes in expenditure to electronics consumption

Beside import, production of electrical and electronic equipment increase significantly in Bangladesh in the recent years due to high local demand. A report published by Bangladesh Bureau of Statistics visualize the picture of expenditure on electronics consumption (Government of Bangladesh, 2017). The report says production of some selected EEE increases up to $750.77 \%$ in the year 2015-16 from the base year 2005-06. Production of communication equipment (television, phone) increases $133.36 \%$ in the last 10 years. Electric motors, generators, and transformer production increases 150.97\%; Batteries 131.70\%; Wires and Cables 291.92\%; Domestic appliance 114.66\%. The highest, $750.77 \%$ increment is observed in Electric Lamps production during the last ten years due to massive electrification in Bangladesh.

All the equipment mention are considered important sources of e-waste generation as these become obsolete after a short time span and marely recycled. Batteries and electric lamps are posing treat to environment most because, harmful components of these items are directly thrown into environment without any treatment that pollute air, water, and soil. The following table presents yearly growth in production of selected electrical equipment in Bangladesh. 
Table 5: Price Indices of Domestically Produced E-goods by Industry Group (Base: 200506=100) (Government of Bangladesh, 2017)

\begin{tabular}{|l|c|c|c|c|c|c|c|c|c|}
\hline \multirow{2}{*}{ Industry } & \multicolumn{7}{|c|}{ Fiscal Year } \\
\cline { 2 - 10 } & $\mathbf{0 7 - 0 8}$ & $\mathbf{0 8 - 0 9}$ & $\mathbf{0 9 - 1 0}$ & $\mathbf{1 0 - 1 1}$ & $\mathbf{1 1 - 1 2}$ & $\mathbf{1 2 - 1 3}$ & $\mathbf{1 3 - 1 4}$ & $\mathbf{1 4 - 1 5}$ & $\mathbf{1 5 - 1 6}$ \\
\hline $\begin{array}{l}\text { Communication equipment } \\
\text { (TV, Phone) }\end{array}$ & 101.05 & 101.05 & 106.31 & 106.07 & 108.88 & 109.46 & 110.69 & 119.56 & 133.36 \\
\hline $\begin{array}{l}\text { Electric Motors, Generators, } \\
\text { transformers }\end{array}$ & 115.96 & 116.63 & 116.63 & 120.17 & 122.38 & 122.79 & 123.23 & 133.35 & 150.97 \\
\hline Batteries & 100.10 & 100.12 & 111.78 & 100.33 & 100.28 & 104.63 & 126.29 & 126.28 & 131.70 \\
\hline Wires and Cables (elec.) & 100.62 & 100.62 & 100.67 & 125.53 & 199.93 & 200.29 & 200.02 & 208.05 & 291.92 \\
\hline Electric Lamps & 132.58 & 147.45 & 176.12 & 212.82 & 281.85 & 334.78 & 422.98 & 541.34 & 750.77 \\
\hline Domestic Electrical appliances & 53.10 & 106.95 & 106.95 & 109.26 & 109.26 & 112.04 & 112.13 & 75.94 & 114.66 \\
\hline
\end{tabular}

Graph 4: Price Indices of Domestically Produced E-goods by Industry Group (Base: 200506=100) (Government of Bangladesh, 2017)

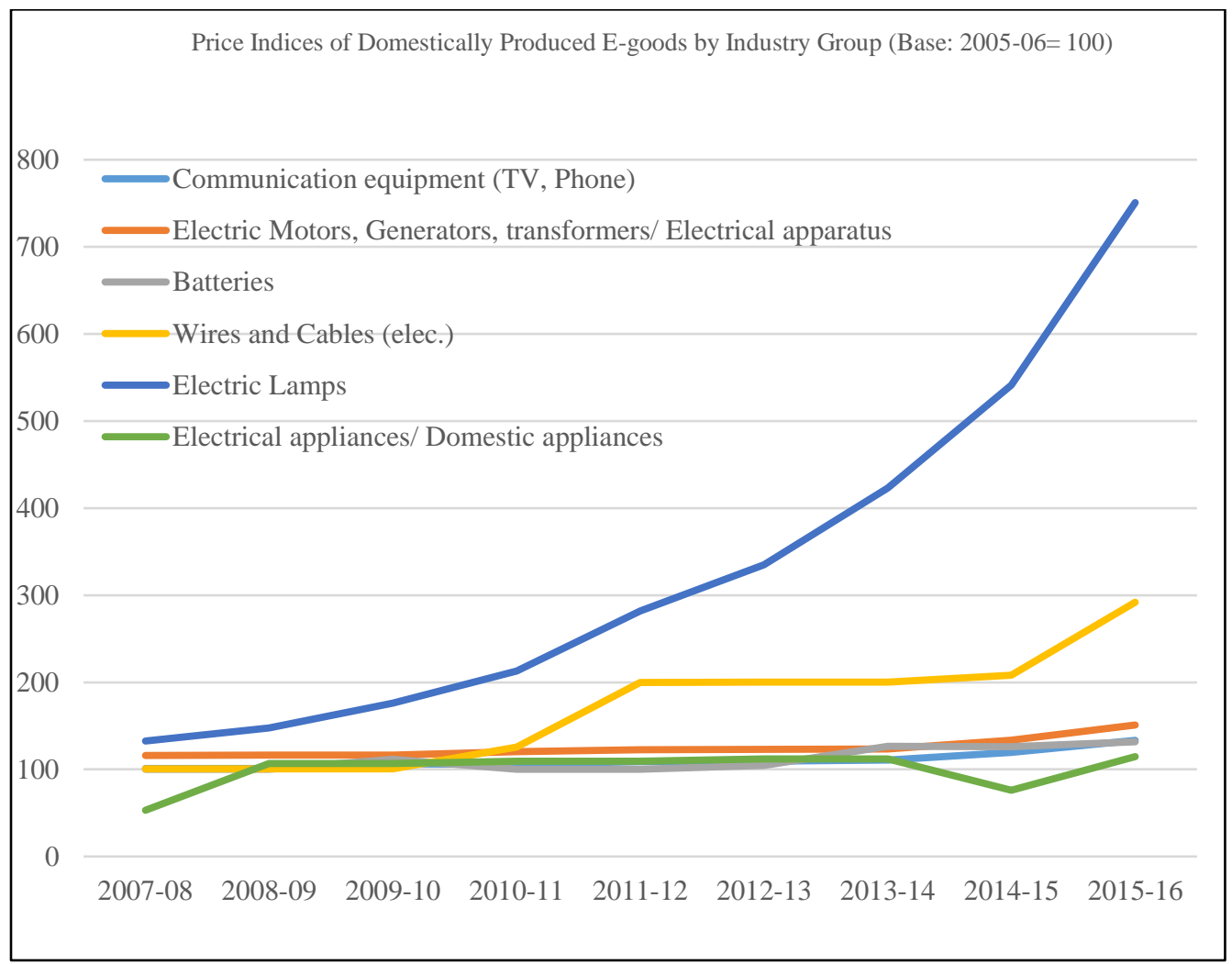

Bangladesh is a big market for different electronic and ICT goods brand or non-brand. In 2017 Bangladesh spent 2546.1 million USD for import of top ten categories of such item. Of them, smart-phone is at the top. Expenditure for importing phone system and smart-phone was 949.4 USD with 5.4 percent of yearly growth. Other items are electrical converter or power unit, electric generation sets, insulated wire/cable, electric storage batteries, electrical or optical circuit boards, electric motor and generator, television receiver, monitors, projectors and low-voltage switches and fuses. The table below shows categorically the expenditure and yearly growth of import of top electrical and electronic items. 
Table 6: Top ten most spent electronics sub-categories in 2017 (Workman, 2018)

\begin{tabular}{|c|l|c|c|}
\hline Rank & \multicolumn{1}{|c|}{ Name of the electronic equipment } & $\begin{array}{c}\text { Expenditure } \\
\text { Million USD }\end{array}$ & $\begin{array}{c}\text { Yearly } \\
\text { Growth (\%) }\end{array}$ \\
\hline $\mathbf{1}$ & Phone system device including smart phone & 949.4 & 5.4 \\
\hline $\mathbf{2}$ & Electrical converter/power units & 314.7 & 39 \\
\hline $\mathbf{3}$ & Electric generating sets, converter & 284.2 & 50.5 \\
\hline $\mathbf{4}$ & Insulated wire/cable & 211.2 & 5.4 \\
\hline $\mathbf{5}$ & Electric storage batteries & 170.0 & 20.3 \\
\hline $\mathbf{6}$ & Unrecorded sound media & 161.2 & 34.4 \\
\hline $\mathbf{7}$ & Electrical/optical circuit boards & 141.1 & 43.5 \\
\hline $\mathbf{8}$ & Electric motor, generators & 109.8 & $(-) 0.6$ \\
\hline $\mathbf{9}$ & TV receivers/monitors/projectors & 103.3 & $(-) 36.1$ \\
\hline $\mathbf{1 0}$ & Lower-voltage switches, fuses & 101.2 & 1.8 \\
\hline
\end{tabular}

Figures presented in the table imply that annual growth in expenditure for most of the items is very significant. For example, import of electric generating sets and power convertors increase 50.5 percent higher than the previous year due to frequent load shading and a recent boost in income of some segment of people.

Graph 5: Top ten electronics sub-categories for those Bangladesh spends most in 2017 (Workman, 2018)

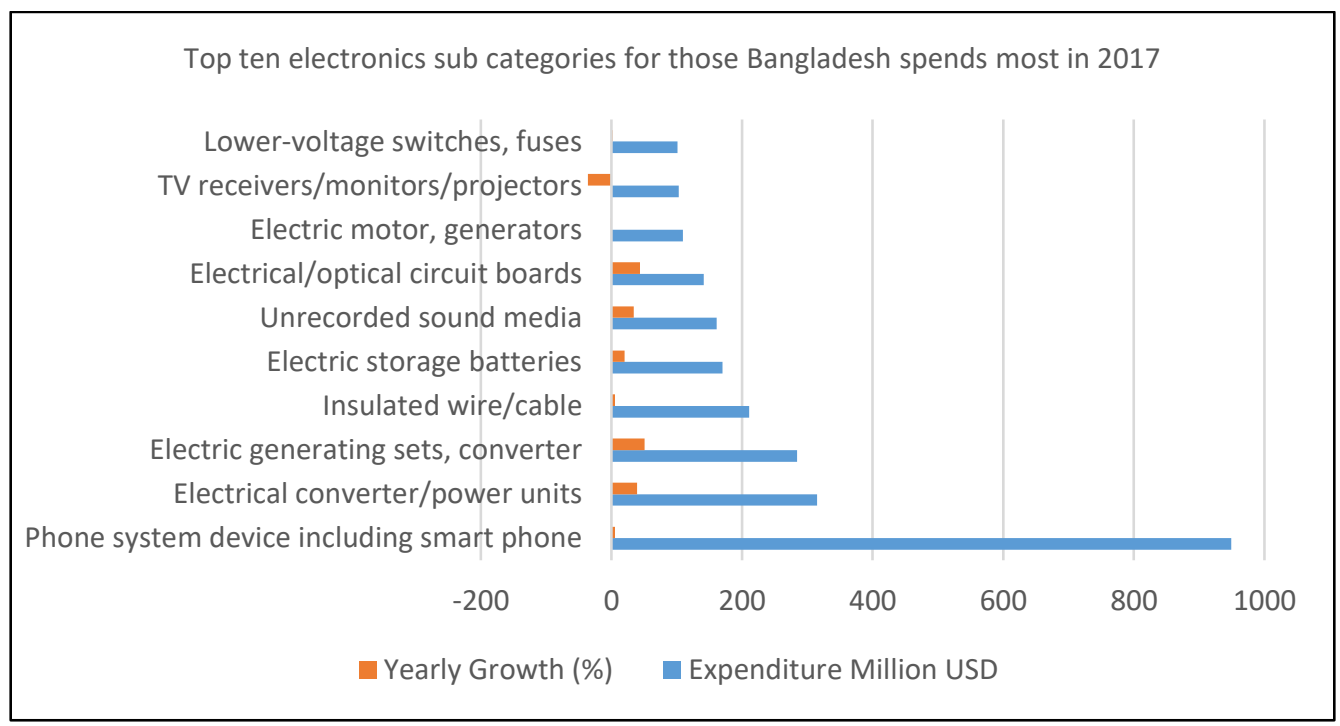

Bangladesh imported a large amount of electronic goods as economic activities have got momentum and prominence shifted to the service sector in recent years. Analyzing import data of the last five years, it is found that Bangladesh spent most (52,295 million Taka) for importing electric filament and or discharge lamps, though the growth rate for the last five year is negative $(-3 \%)$. It is because of awareness in using energy saving CFL or LED lighting bulbs for the recent years. Primary cells and primary batteries are the second highest category both in gross expenditure and percentile growth in the last five fiscal year. Total payments for importing primary cells and primary batteries were 33,682 million BDT five hundred percent growth rate during the period. Bangladesh also imported printed circuit boards- a vital source of value carrying e-waste. 
Table 7: Five-year Import of Selected Commodities fall into electronics sub-categories 2012-13 to 2016-17 in million BDT (Bridgat, 2018)

\begin{tabular}{|c|c|c|c|}
\hline $\begin{array}{l}\text { Electronic equipment/ } \\
\text { Commodities }\end{array}$ & $\begin{array}{c}\text { Total in } \\
5 \text { Year }\end{array}$ & $\begin{array}{l}\text { Electronic equipment/ } \\
\text { Commodities }\end{array}$ & \begin{tabular}{|c|}
5 year \\
Growth \%
\end{tabular} \\
\hline Electric filament/discharge lamps & 52295 & Electro-mechanical tools with motor & 805 \\
\hline Primary cells and primary batteries & 33682 & Primary cells and primary batteries & 499 \\
\hline Transmission apart radio-telephone, tv, etc. & 19377 & Insulated wire, optic fiber cable, etc. & 190 \\
\hline Turntable, record/cassette player, etc. & 16156 & $\begin{array}{l}\text { TV including video } \\
\text { monitors/projectors }\end{array}$ & 150 \\
\hline Electro-mechanical domestic appliance & 7002 & Microphone loudspeaker, headphone etc & 124 \\
\hline Video-recording/reproducing apparatus & 6253 & $\begin{array}{l}\text { Radar radio navigation aid etc. } \\
\text { apparatus }\end{array}$ & 104 \\
\hline Radar radio navigation aid etc. apparatus & 4535 & $\begin{array}{l}\text { Electronic accumulator, including } \\
\text { separator }\end{array}$ & 66 \\
\hline Microphone loudspeaker, headphone etc & 2487 & $\begin{array}{l}\text { Electric light/ signaling equipment, } \\
\text { etc }\end{array}$ & 58 \\
\hline Printed circuit board & 2469 & $\begin{array}{l}\text { Video-recording/reproducing } \\
\text { apparatus }\end{array}$ & 55 \\
\hline TV including video monitors/projectors & 1486 & $\begin{array}{l}\text { Electro-mechanical domestic } \\
\text { appliance }\end{array}$ & 46 \\
\hline Electro-mechanical tools with motor & 871 & $\begin{array}{l}\text { Transmission apart radio-telephone, } \\
\text { tv, etc. }\end{array}$ & 35 \\
\hline $\begin{array}{l}\text { Electronic accumulators, including } \\
\text { separator }\end{array}$ & 596 & Printed circuit board & 19 \\
\hline Electric light/ signaling equipment, etc & 527 & Turntable, record/cassette player, etc. & 1 \\
\hline Insulated wire, optic fiber cable etc & 273 & Electric filament/discharge lamps & -3 \\
\hline
\end{tabular}

Bangladesh spent BDT 2469 million in last five year for importing printed circuit board. The reason behind this is, an informal sector of electronic equipment assembling and repairing in an indigenous method flourished recently in Bangladesh. Many self-educated technician, cum entrepreneur are engaged in refurbishing various types of electronic products like IPS, table fan, Rechargeable lamp, and repairing personal computer, smart mobile phone, etc.

A survey run by BBS, finds access, usage, and ownership of radio, television, computers, mobile phones, fixed-line telephones, and internet facilities. The ICT sector is pivotal in raising labor productivity and enhancing competitiveness in Bangladesh. Generally household income is an important determinant of household ownership of personal computers, mobile phones, and internet access. (Government of Bangladesh, 2015).

\section{Use and Access of ICT by Household}

At the national level, 4.8 percent of the household have internet access at home and 5.7 percent of households have a personal computer. The survey also presents that 46 percent of households has at least one television in their house. The use of mobile phone in Bangladesh reached almost at saturation as 87.7 percent of households have access to mobile phones of their own. Though the figure is small in some case, it has a great significance in e-waste generation. For example, 427,616 households have a personal computer ( $5.7 \%$ of total 7502040 households in Bangladesh). Considering average 29.6 kilogram of weight per PC and three years of its life span, 12,657.44 metric tons of e-waste is generated in every three years from an electronic equipment, Personal Computer in Bangladesh. 
Graph 6: Households Percentile Access to the ICT at National Level, Bangladesh

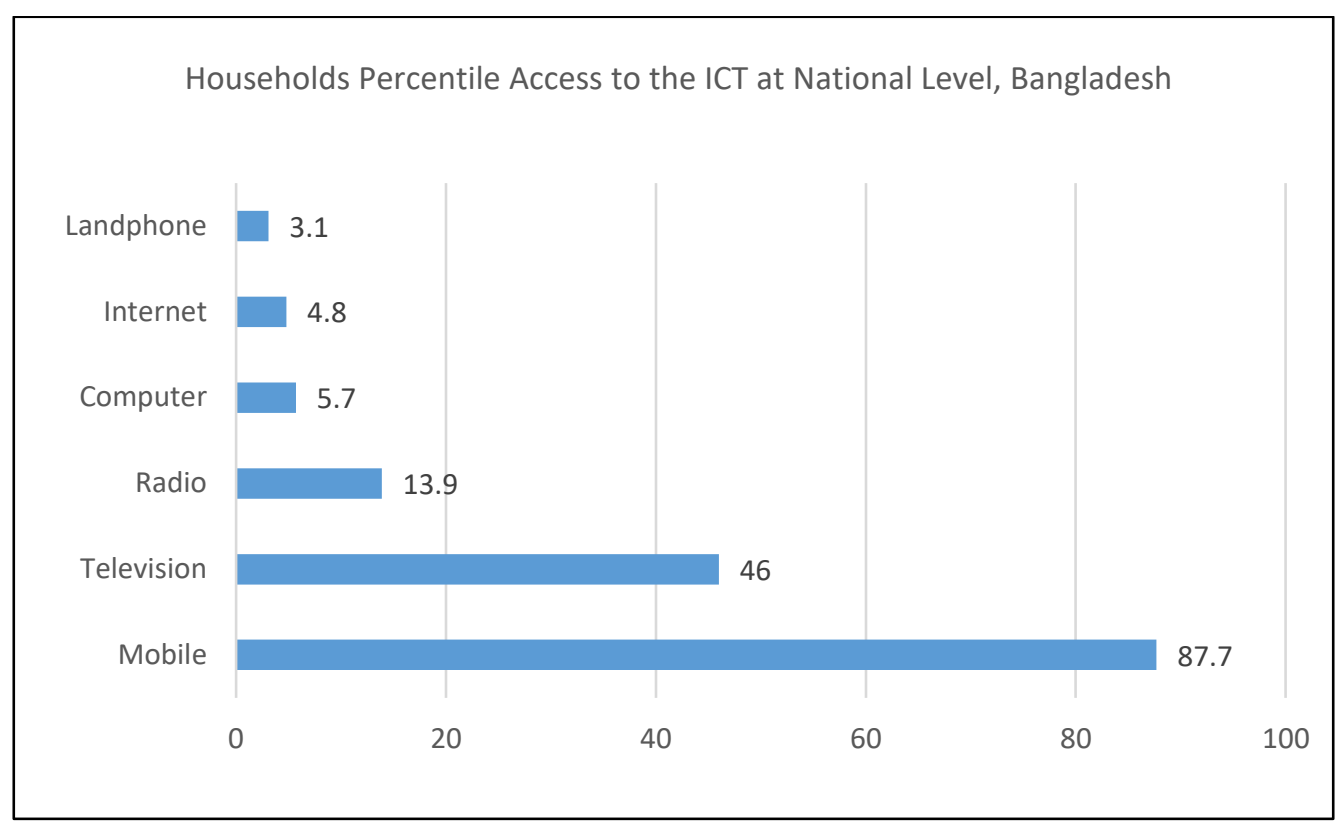

\section{The spatial pattern of ICT and electronics use}

Like all other parameter, Dhaka is unique in ICT and EEE consumption as population, and economic opportunities are concentrated here with advanced digital culture. But, there is some digital disparity in the regional context. Considering mobile phone usages, 90.97 percent of household in Dhaka district have access to mobile phone. Top ten regions excluding Dhaka regarding cell phone density are Feni, Chittagong, Munshiganj, Gazipur, Comilla, Madaripur, Brahmanbaria, Sariatpur, and Faridpur. In Dhaka district, 73.76 percent of the household has provision to TV/Radio, followed by Narayangang, Munshiganj, Chittagong, Gazipur, Feni, Rajshahi, Khulna, Jhenaidah, and Joypurhat.

Table 8: Rank of Districts by ICT Use and Access to electronic equipment by Households Bangladesh (Percent of households have access to particular amenity) (Government of Bangladesh, 2015)

\begin{tabular}{|c|l|l|l|l|l|}
\hline Rank & Telephone & Mobile & TV/Radio & Computer & Fridge \\
\hline $\mathbf{1}$ & Dhaka & Dhaka & Dhaka & Dhaka & Dhaka \\
\hline $\mathbf{2}$ & Chittagong & Feni & Narayanganj & Chittagong & Munshiganj \\
\hline $\mathbf{3}$ & Sylhet & Chittagong & Munshiganj & Gazipur & Narayanganj \\
\hline $\mathbf{4}$ & Khulna & Munshiganj & Chittagong & Sylhet & Chittagong \\
\hline $\mathbf{5}$ & Gazipur & Gazipur & Gazipur & Narayanganj & Feni \\
\hline $\mathbf{6}$ & Rajshahi & Comilla & Feni & Rajshahi & Gazipur \\
\hline $\mathbf{7}$ & Brahmanbaria & Madaripur & Rajshahi & Khulna & Sylhet \\
\hline $\mathbf{8}$ & Narayanganj & Brahmanbaria & Khulna & Feni & Comilla \\
\hline $\mathbf{9}$ & Jessore & Shariatpur & Jhenaidah & Narshingdi & Brahmanbaria \\
\hline $\mathbf{1 0}$ & Narshingdi & Faridpur & Joypurhat & Jessore & Khulna \\
\hline
\end{tabular}


Map 1: Districts fall into top ten of electronic consumption in Bangladesh (Government of Bangladesh, 2015)

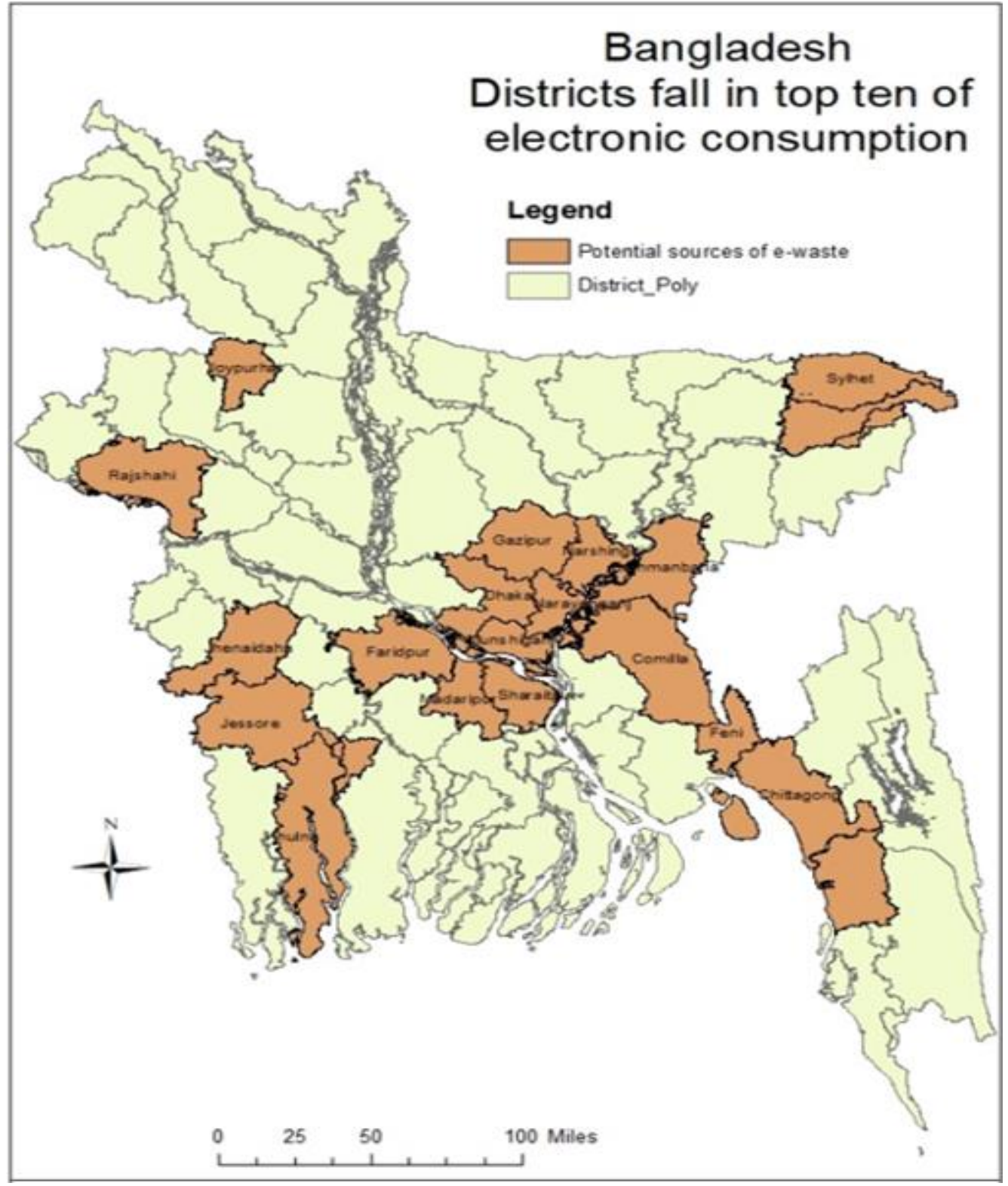

\section{CONCLUSION}

The study concludes that consumption of electrical and electronic equipment is related to population density and age structure. In urban area, consumption is much higher than the rural area of Bangladesh because of high population concentration, the scope of better income, and way of urban life. Dhaka is the only district or city in Bangladesh where all type of electronic equipment is consuming most considering that of all other regions. In Bangladesh, new generation, especially the young folks are vital in consuming electronic 
equipment as they are sometimes directed by trend and advertisement. On the other hand, Government should be long sighted on permitting open access to electronic equipment and promoting digitalization so that the junk generated from using electronics could be managed properly. It is the high time to regulate the import of electrical and electronic equipment considering the actual necessity and thinking healthier environment.

\section{ACKNOWLEDGEMENT}

This paper is a part of Md. Zahidul Islam's ongoing Ph.D. research work at Institute of Bangladesh Studies, Rajshahi University, Bangladesh. The author gratefully acknowledges the Secondary and Higher Education Division (SHED), Ministry of Education, Bangladesh; Directorate of Secondary and Higher Education (DSHE), Dhaka, Bangladesh; and University Grant Commission, Bangladesh for providing fellowship for the research.

\section{REFERENCES}

Alam, M., \& Khalid, M. B. (2015). Electrical Waste in Bangladesh: Evaluation of the Situation, Legislation and Policy and Way Forward with Strategy and Approach. PESD 9, no. 1.

Bridgat (2018). Top Products Imported by Bangladesh. Retrieved December 16, 2018, from Bridgat.com: http://countries.bridgat.com/Top_Products_Imported_by_Bangladesh.html

Government of Bangladesh. (2014). Population and Housing Census 2011 National Volume-3: Urban Area Report. Dhaka: Bangladesh Bureau of Statistics (BBS).

Government of Bangladesh. (2015). Report on ICT Use and Access by Individual and Households Bangladesh 2013. Retrieved October 15, 2018, from bbs.gov.bd: http:/ /203.112.218.65:8008/WebTestApplication/userfiles/Image/LatestReports/ICTUseAcces sSurvey2013.pdf

Government of Bangladesh. (2017). Statistical Year Book 2017. Dhaka: Bangladesh Bureau of Statistics.

Karim, R. T., Bari, N., \& Amin, M. A. (2014). E-waste Management in Bangladesh. 2nd International Conference of Green Energy and Technology.

Lepawsky, J., \& Billah, M. (2011). Making Chains that (Un)make Things: Waste-Value Relations and the Bangladeshi Rubbish Electronics Industry. Geografiska Annaler. Series B, Human Geography, Vol. 93, No. 2, 121-139.

Partha, S., \& Hasan, M. (2011). ICTs and Environmental Sustainability: Mapping National Policy ContextsBangladesh Baseline Study. Dhaka: Association for Progressive Communications (APC) and Bytes for All.

Shahriar, H., Sultana, S., Shahanaz, F., Akram, A. B., Nesa, M., Happell, J., \& Hossain, M. L. (2010). Study Report on E-waste: Bangladesh Situation. Dhaka: Environment and Social Development Organization (ESDO).

The World Bank. (2010). Global Consumption Database Audio-Visual, Photographic and Information Processing Equipment. Retrieved October 17, 2018, from datatopics.worldbank.org: http://datatopics.worldbank.org/consumption/product/Audio-Visual,-Photographic-andInformation-Processing-Equipment

The World Bank. (2010). Global Consumption Database. Retrieved December 16, 2018, from The World Bank Working for the World Free of Poverty: http:/ / datatopics.worldbank.org/consumption/sector/ICT

Workman, D. (2018, May 11). Bangladesh's Top 10 Imports. Retrieved December 16, 2018, from World's Top Exports: http:/ / www.worldstopexports.com/bangladeshs-top-10-imports/ 